\title{
Modeling of psychological support of persons with disabilities at the University
}

Karpushkina N. V. ${ }^{1}$

Kisova V. V. ${ }^{2}$

Koneva I. A. ${ }^{3}$

Kochneva E. M. ${ }^{4}$

Kudryavtsev V. A. ${ }^{5}$

Rossova Y. I. ${ }^{6}$

Fedoseeva N. V. ${ }^{7}$

\section{Journal for Educators, Teachers and Trainers, Vol. 12 (1)}

\author{
https://jett.labosfor.com/
}

Date of reception: 18 September 2020

Date of revision: 17 Dec 2020

Date of acceptance: 15 March 2021

Karpushkina N. V., Kisova V. V., Koneva I. A., Kochneva E. M., Kudryavtsev V. A., Rossova Y. I., Fedoseeva N. V. (2021). Modeling of psychological support of persons with disabilities at the University. Journal for Educators, Teachers and Trainers, Vol. 12(1). 1 - 7.

\footnotetext{
$\overline{1,2,3,4,5 \text { Cand. the course of studies. PhD }}$, associate Professor, Department of special pedagogy and psychology of Minin Nizhny Novgorod State Pedagogical University, Russia, Nizhny Novgorod

${ }^{6}$ Cand. PED. N., associate Professor, associate Professor of the Department of pedagogy of preschool and primary education, Arzamas branch of NNSU, Russia, Arzamas

${ }^{7}$ Cand. PED. Professor, associate Professor, associate Professor of the Department of General pedagogy and pedagogy of professional education, Arzamas branch of NNSU, Russia, Arzamas
} 


\title{
Modeling of psychological support of persons with disabilities at the University
}

Karpushkina N. V. ${ }^{1}$, Kisova V. V. ${ }^{2}$, Koneva I. A. ${ }^{3}$, Kochneva E. M. ${ }^{4}$, Kudryavtsev V. A. ${ }^{5}$, Rossova Y. I. ${ }^{6}$, Fedoseeva N. V. ${ }^{7}$,

${ }^{1,2,3,4,5}$ Cand. the course of studies. PhD, associate Professor, Department of special pedagogy and psychology of Minin Nizhny Novgorod State Pedagogical University, Russia, Nizhny Novgorod

${ }^{6}$ Cand. PED. N., associate Professor, associate Professor of the Department of pedagogy of preschool and primary education, Arzamas branch of NNSU, Russia, Arzamas

${ }^{7}$ Cand. PED. Professor, associate Professor, associate Professor of the Department of General pedagogy and pedagogy of professional education, Arzamas branch of NNSU, Russia, Arzamas

\begin{abstract}
The article is devoted to the description of modern approaches to modeling of psychological and pedagogical support of persons with disabilities and disabilities in higher education. The article presents a model of psychological and pedagogical support of students with disabilities at the main stages of higher education, describes in detail the structural components of complex support.

The aim of the study was to develop a model of psychological and pedagogical support for persons with disabilities and disabilities in the University. The targets, main directions and content of students ' support in the conditions of an inclusive University are defined.

The main directions of psychological and pedagogical support of persons with disabilities and disabilities in the University are: education, diagnosis, counseling, prevention, correctional and developmental work, research (methodological) activities, etc. The article describes in detail the content of these areas for students with disabilities and disabilities. These directions are realized both in work with students, and their parents, teachers of the higher school.

The modeling of psychological and pedagogical support of inclusive higher education is based on the following principles: the principle of expansion and formation of tolerant "barrier-free" space, the principle of subjectivity and socialization, the principle of motivation and activity, the principle of diabolicality, the principle of variability.
\end{abstract}

Keywords: psychological and pedagogical support; inclusive education; model of support; a person with disabilities; diagnosis; counseling; correctional and developmental work; education

\section{INTRODUCTION}

The project "Concept of development of psychological service in the education system of the Russian Federation" (up to 2025) notes new guidelines in the organization of psychological support at the University: the preservation and strengthening of psychological health, improving psychological culture, early identification of personal and social problems.

\section{LITERATURE REVIEW}

The concept of psychological support in the University is at the stage of formation. Psychological researches of the last few years consider various aspects of its organization (V. A. Bodrov, A. K. Markova, Yu. P. Povarenkova, L. G. Semushina, V. V. Serikova, Sorokoumova S. N., Kudryavtsev V. A., Kashtanova S. N., Karpushkina N. V., Medvedeva E. Yu., etc.).

In researches Kazakova E. I., Makarova I. V., Umnyashova E. B. actual problems of psychological support of University students are analyzed. Central are the problems in adapting to the conditions of study at the University, the problems of interpersonal relations with classmates and teachers, problems in the organization of training, the decline in academic performance, the problems of choosing a professional route and building a career.

These areas of support are distributed as follows:

First-year students need organizational and pedagogical support of the process of adaptation in the Universityestablishing relationships with classmates and teachers, the formation of new ways of educational activity. 
For students of 2-3 courses psychological and pedagogical support can be aimed at solving problems of further professionalization, formation of educational motivation, conflict resolution with teachers.

For students of 4-5 courses, employment, adaptation to the "situation of the final course"becomes relevant. Difficulties of many graduate students are also associated with the need to combine educational and professional activities.

Thus, in modern researches the questions of target orientations in the organization of psychological and pedagogical support of University students are actualized, some organizational and methodical approaches to its realization are presented. At the same time, there is no model of psychological and pedagogical support of students with the inclusion of all subjects of the educational process, there are no approaches to its implementation in relation to persons with disabilities and disabilities $(1,4,5,7,8,13,16,17)$.

\section{MATERIALS AND METHODS}

In this regard, the purpose of our research is to develop and test a model of psychological and pedagogical support for persons with disabilities and disabilities in high school.

Based on the target component the following tasks were formulated:

1. Development of methodological approaches to modeling tolerant "barrier-free" space, providing conditions for learning, socialization and self-realization of persons with disabilities.

2. Ensuring the implementation of an integrated approach in the organization of psychological and pedagogical support of persons with disabilities in higher education.

3. Development of approaches to the implementation of psychological and pedagogical support of the main subjects included in the inclusive processes of the University.

In the course of the study we used the methods of theoretical analysis and generalization, expert evaluation.

\section{RESULTS}

In the organization of psychological and pedagogical support at the University, two types of programs are used: individually - oriented and system-oriented. Individual-oriented support is aimed at solving the problems of a particular person, system-oriented support is designed to prevent the occurrence or solution of problems specific to a large group of people.

According to the results of the study, students with disabilities need both individually-oriented and system oriented support. Individual-oriented programs will help first-year students to adapt to new learning conditions, providing assistance and support in accepting these conditions, correction of professional self-determination.

System-oriented programs in the mode of psychological and pedagogical support provide assistance in the formation of motivation and value - semantic attitude to the chosen profession and specialty, in the formation of professionally significant qualities, the development of necessary competencies.

Also, this type of programs is aimed at the formation of readiness for conscious, independent planning, adjustment and implementation of professional development plans, readiness to make decisions about employment and career development, the formation of skills of behavior in the labor market.

There are 4 stages of psychological support of students at the University: career guidance, adaptation, specialization and professionalization.

The main principles of psychological and pedagogical support of students with disabilities and disabilities in the University are:

-maximum consideration of individual development, health and rehabilitation potential of students with disabilities;

- orientation of training on formation of educational and communicative skills, professional and social adaptation, employment;

- development of skills of the analysis and adequate perception of results of the educational activity, formation of skills of research work;

- creating conditions for the development of the abilities of students with disabilities, ensuring the ability to selfrealization;

- establishment of adequate interpersonal relationships with peers, teachers, creating a comfortable psychological climate in the University; 
- ensuring cooperation of the University with the family of the student on topical issues of psychological and pedagogical support of persons with disabilities in the University;

creation of conditions for the organization of complex support at all stages of education.

The implementation of the principles is based on the following conditions:

- organization of advanced training courses for scientific and pedagogical workers and employees of structural units of the higher school. It is necessary to organize work on the formation of knowledge about the features of the psychological status of students with disabilities and disabilities, the specifics of the adaptation period, the features of professional self-determination, the use of technical means of training, taking into account the main variants of dysontogenesis;

- development and implementation (on request) of adapted educational programs, with adequate selection of adaptation modules (adaptation disciplines);

- providing comprehensive psychological and pedagogical support of the process of teaching students with disabilities in the process of obtaining higher education;

- development, if necessary, of individual curricula and individual study schedules, allowing to study at the University (together with other students or in separate groups), at home using e-learning, distance learning technologies;

-active inclusion of students with disabilities and disabilities in the social project, volunteer activities of the University;

- involvement of curators and student mentors to help students with disabilities adapt to the educational process;

- methodological assistance to curators of academic groups to identify problems arising in students with disabilities and disabilities in the process of educational and extracurricular activities;

- support of intellectual initiative and development of creativity of students with disabilities, their inclusion in research activities, as well as mentoring in relation to University students with disabilities;

- interaction with the administration of the University dormitories in order to successfully adapt students with disabilities and disabilities, the formation of their skills of social interaction;

- attraction to cooperation of qualified specialists in the field of medical and rehabilitation services to inform students with disabilities about the benefits and the possibility of obtaining them;

- attraction of students with disabilities to active activity in the student activity of the University;

- emphasis on self-knowledge, self-manifestation in various situations of development of students with disabilities and disabilities, prevention of overprotection.

The implementation of these principles and conditions in our model is carried out in the main activities of psychological and pedagogical support:

1. Consultancy.

2. Psychological diagnosis.

3. Psychocorrective and developmental work.

4. Education.

5. Psychological prevention.

6. Research (methodical) activity.

\section{DISCUSSION}

As the results of the study show, the following psychodiagnostic measures are most effective in the organization of psychological and pedagogical support:

Diagnostics of adaptation of first-year students in order to identify risk groups.

Diagnostics of interpersonal relations in student groups.

Diagnostics of communicative and organizational abilities, emotional and volitional characteristics of students and other features of students that influence the educational process.

Diagnosis of professional inclinations, interests, motives, professional personality type in order to determine the professional trajectory of development and future employment.

Monitoring the progress of students, including those with disabilities and disabilities.

One of the most popular activities for psychological and pedagogical support is psychological counseling.

Consulting activities are carried out at all stages of the work. 
With entrants and their parents (legal representatives) are consulted on vocational guidance, the choice of direction and profile of training.

Advising first-year students helps them to successfully adapt to the new learning process at the University.

In the first year there are also often problems of establishing interpersonal relations in the student group and conflicts with teachers.

In the second or third year of study, students may have doubts in choosing the direction of training, and, as a consequence, a decrease in educational motivation and interest in learning.

Graduate students may need counseling in connection with the need to address issues related to employment in the chosen profession, preparation for an interview for employment.

Often the reason for seeking advice was the negative manifestations of the psycho-emotional sphere, conflict situations with parents. Psychological counseling at the University is carried out in both individual and group forms. Often psychological counseling at the University is carried out on the self-request of a psychologist.

An urgent task in the organization of psychological counseling is also to advise teachers, administration, employees of structural units of the University, parents on psychological problems in communication, training and education of students, in the development of their communicative characteristics, etc.

Individual and group consultations of students on training, development, problems of self-determination, selfeducation, relationships with the opposite sex are in demand at the University.

Correctional and developmental work by specialists of the support service of the University is carried out, first of all, with students "at risk", with special educational needs, learning difficulties and adaptation.

As the results of the study show, the most relevant areas of development work at the University are:

- development of cognitive sphere of students: attention, imagination, thinking, memory, etc.;

- removal of anxiety, the formation of adequate self-esteem;

- development of skills of self-organization and self-control;

- increased resistance to stress;

- correction of inadequate settings for the choice of profession;

- adaptation of first-year students to the learning process at the University.

The most popular forms of work are: master classes, trainings, training seminars, organization of practices, internships, thematic seminars, discussion platforms, round tables, panel discussions.

Also, in the course of correctional work, the curators of academic groups are trained, the development of teaching AIDS for participants of the educational process is carried out.

Educational work is carried out both in verbal (counseling, presentations of specialists at career guidance events, meetings with parents, with the administration and scientific and pedagogical workers) and in non - verbal (booklets, brochures, manuals, websites) forms.

The Portal of inclusive education is actively used in the process of educational work at Minin University. It is a search engine information system, analytical database and an effective tool for adjustment and moderation of educational resources. The portal acts as an effective tool for information and analytical support, where the main subjects of support are persons with disabilities and disabilities, parents, research and teaching staff and employees of structural units of the University, employers. The portal is intended for representatives of regional resource educational and methodical centers for training of persons with disabilities, representatives of the Ministry of education and science of Russia and other bodies.

The portal also performs the task of monitoring the accessibility of higher education for persons with disabilities and disabilities. The portal regularly updates information about the availability of special training conditions for students with HIA. This is done in the personal account of the educational organization on the portal.

Psychological prevention is understood as purposeful systematic joint work of specialists:

- to prevent possible social and psychological problems in all participants of the educational process;

- to identify different risk groups (for various reasons): students experiencing difficulties in adaptation and educational activities; employees of educational organizations who begin to show symptoms of professional burnout, etc.;

- to create a favorable emotional and psychological climate in the teaching and student groups.

The main forms of work on psychological prevention in the University are trainings, consultations, etc. in order to form psychological competence and readiness for activity. 
In the course of psychological and pedagogical support of persons with disabilities and disabilities are also relevant issues of prevention of maladjustment and suicidal risks. In this case, students are trained in social technologies, which are included in the content of the social part of professional competence.

Scientific-methodical activity is provided by scientific and teaching staff of the University, a psychologist and involves the development of scientific and methodical materials for applicants, students and their parents, specialists of educational and social institutions; the development of technologies of practice-oriented training of students; methodological assistance to students in the preparation of publications, participation in conferences, preparation and organization of scientific research; organization of conferences, seminars on actual problems of psychology of education; organization of research activities, professional competitions, etc.

The criteria for the success of the process of psychological support of students at the University will be:

- successful adaptation of first-year students to the educational process;

- maintaining the contingent of students for the entire period provided for by the main educational program of the direction of training (or a slight decrease in it);

- satisfaction of students with the results of their educational and extracurricular activities;

- employment of graduates in the chosen profession and their adaptation in the workplace for at least a year.

\section{CONCLUSION}

Thus, the support of students with disabilities at the University should be carried out in the system of complex support, taking into account the different variants of dysontogenesis.

For students with disabilities, it is possible to develop both individually-oriented and system-oriented programs of psychological and pedagogical support for the entire period of study.

The implementation of the program of psychological and pedagogical support should be comprehensive, systematic, based on the main activities of specialists (diagnostic, educational, correctional and developmental, preventive, Advisory).

\section{REFERENCES}

1. Evensky I. V., Sorokoumova S. N., Suvorova O. V. Professional readiness of future teachers to work with students with disabilities and disability in the inclusive practice// the Bulletin of Minin University. Volume 6. No. 1. (2018). https://doi.org/10.26795/2307-1281-2018-6-1-12

2. Kashtanova S. N., Medvedeva E. Yu., Kudryavtsev V. A., E. A. Olkhina. Karpushkina N. V. Monitoring the activities of universities as a basis for the strategic development of inclusive higher education. Revista Espacions. Tom. 38 (No 56) 2017. p. 23.

3. Karpushkina N. V. Information and analytical system of support of activity of educational organizations in the sphere of inclusive professional education of disabled people and persons with disabilities: modern tendencies / SB. Strategic lines of development of inclusive higher education at the present stage collection of articles on materials of the International scientific and practical conference. Nizhny Novgorod state pedagogical University named after Kozma Minin. 2018. Pp. 180-184.

4. Karpushkina N. V. Modern strategies of modeling information and analytical support of inclusive higher education/ / Psychological science and education. 2017. T. 22. No. 1. Pp. 161-168.

5. Karpushkina N. V., Koneva I. A. to the problem of modeling information and analytical support of inclusive higher education. Problems of modern pedagogical education.- Yalta: RIO GPA, 2016. Vol. 53. Part 6. Pp. 190-200.

6. Karpushkina N. In. Alehina E. A. Analysis of models of support for inclusive higher education in the countries of Western Europe and Russia// Vestnik of Minin University. 2016. No. 4. Pp. 31-39.

7. Kashtanova S. N., Kudryavtsev, V. A. Career routing as a strategy professional and personal development of persons with disabilities and disability// journal of Minin University.Vol. 6-No. 2 (2018). https://doi.org/10.26795/2307-1281-2018-6-2-13

8. Kashtanova S. N., Kudryavtsev V. A. on some trends and problems in the development of educational institutions of higher education and regional resource centers of higher education, 
teaching persons with disabilities and disabilities according to the results of monitoring.Vestnik Mininskogo universiteta. Volume 16. No. 3 (2017) https:// doi.org/10.26795/2307-1281-2017-3-11

9. Kashtanova S. N., filchenkova I. F. Criteria base for monitoring the activities of universities and regional resource centers for training persons with disabilities and disability / / Modern scientific research and innovation. 2016. No. 10 [Electronic resource]. URL: http://web.snauka.ru/issues/2016/10/72157.

10. Kudryavtsev V. A., Kashtanova S. N. Monitoring of the conditions for the implementation of inclusive higher education in Russian universities.Vestnik Mininskogo universiteta. 2016. No. 3. Pp. 23-31.

11. Medvedeva E. Yu. Olkhina E. A. Comparative analysis of the development of the system of inclusive higher education in Russia and Germany / / Problems of modern pedagogical education: Issue 53 Part VII.- 2016 . 340 to 349.

12. Medvedeva E. Yu., Olkhina E. A. Assessment of educational needs of adults with disabilities and disability / / Problems of modern science and education.- Moscow: 2016 . No. 37 (79). From 92 95.

13. Medvedeva E. Yu. Kudryavtsev V. A. Monitoring of activity of higher education institutions and regional resource centers on training of disabled people: problems of inclusive higher education in Russia / / Modern scientific researches and innovations.2016. No. 10. Pp. 481-488.

14. Medvedeva E. Yu., Olkhina E. A. the Role of pre-University training in the system of inclusive higher education.Vestnik Mininskogo universiteta. Volume 6 No. 1 (2018) https://doi.org/10.26795/2307-1281-2018-6-1-9

15. Medvedev E. Yu.., Dvurechensky O. N. Monitoring of the implementation process of inclusive higher education in universities of the Russian Federation// Bulletin of Minin University. 2016. No. 3. Pp. 23-31.

16. Olkhina E. A., Karpushkina N. V., Dvurechenskaya O. N. Monitoring the activities of universities and regional resource centers for learning disabilities: analysis of foreign experience / / Modern scientific research and innovation. 2016. No. 10 [Electronic resource]. URL: http://web.snauka.ru /issues/2016/10/72155.

17. Semenova L. E., Serebriakova T. A. Psychological well-being of students - psychologists with different personal resources of professionally significant characteristics// Bulletin of Minin University. Volume 6. No. 3 (2018) https://doi.org/10.26795/2307-1281-2018-6-3-10

18. Hall J., Tinklin T. Students with disabilities and higher education / / Journal of social policy research. 2004. Vol. - No. 1. Pp. 115-126. 